ExHibirions and fairs are always a source of concern to firms which have to consider how far the results attained justify substantial expense. The Association of British Chemical Manufacturers, not unmindful of the fact that the key industry duties on fine chemicals will, unless removed, expire in 1936, urges manufacturers to exhibit at the forthcoming British Industries Fair in order to show the general public and those in authority how great and wise a use has already been made of that protection. Recent trade statistics show a marked increase in the importation of chemical products which are made in Great Britain ; chemical exports have also increased, but to a smaller extent. Doubtless there is ground for investigation whether the best use is being made of our tariff system, for further attention by manufacturers to the necessity of endeavouring constantly to increase the attractiveness of their products in the world's markets, and for greater consideration by buyers of the claims, ceteris paribus, of home manufactures. The Ottawa agreements have benefited the chemical industry in many directions, although certain unexpected difficulties have arisen. Mr. Carr warned his audience that if the Ottawa idea is to be continued and expanded, there is an urgent need for the economic planning of agriculture and of industry in the Empire. Consideration has lately been given also to the position of the chemical and allied industries in relation to Government-owned patents, and a scheme of cooperation with the Department of Scientific and Industrial Research and the British Chemical Plant Manufacturers' Association has been evolved. Other sections of the report or of the chairman's address referred to safety measures, transport, poisons rules, the fine chemical industry, and the dyestuffs industry.

\section{The Government Laboratory}

Reporting on the work of the Government Laboratory for the year ended March 31, 1934 (London : H.M. Stationery Office, 1934. 9d. net), the Government Chemist, Sir Robert Robertson, refers inter alia to the frequent necessity for investigating work in connexion with chemical tests on imported goods and articles of commerce. He briefly summarises the results of tests applied to dairy products, and once again mentions that there is no standard, as regards fat content, for cream in Great Britain, and no regulations relating to the marking of skimmed or partially skimmed milk cheese. A curious incrustation on the surface of stored marine shells was found to consist of calcium acetate. The shells had been stored in drawers of oakwood, which is known to evolve traces of acetic acid continuously, and the effect was attributed to the localised action of acetic acid attracted by the deliquescent residue from seawater salts. Among the great variety of duties performed by the Laboratory during the year, in addition to numerous analyses of foods, drugs, fertilisers, water, beverages, dyes, oils, silk, etc., were the restoration of medals and plaques for the Imperial War Museum, detection of the fraudulent use of stamps, a search for the cause of earthy flavour in fish, complete analyses of rocks for the Geological Survey, the recovery of radium from decayed luminous paint, and the examination of materials purchased for the public service.

\section{Whale-Marking in South Georgia}

IN view of the complete lack of accurate knowledge on the migrations of whales, the "Discovery" Committee has for the past nine years been conducting experiments in whale-marking. The only practicable method of marking is by shooting a mark into the blubber from a gun. In the first series of experiments the mark used consisted of a barbed pin attached to a disc designed to lie flush with the surface of the body. Numbers of whales were marked by this means, but no marks were returned from those engaged in the whaling industry. At the Marine Biological Station in South Georgia it was found that Pennella, a parasitic copepod which infects whales in temperate and sub-tropical regions, was rapidly extruded from the blubber when the whales visited the cold waters of the Antarctic, and since this parasite is very firmly anchored in its host, it is practically certain that the whale marks were extruded in the same way. Another pattern of mark was devised-a short length of stainless steel tubing fitted with a leaden head. This mark is designed to embed itself completely in the blubber; when once the wound of entry has healed, the mark cannot fall out, and it will be found without difficulty by the whalers when the blubber is stripped from the carcase. Experiments conducted with this pattern give promise of success : five of the marks used have been recovered, three after the lapse of a few weeks and two after thirteen months. In no case was there any sign of suppuration, and in some the wound could not be found. All the whales were in good condition. The Committee is now undertaking whale-marking on a larger scale. One of its scientific staff, Mr. A. H. Laurie, left England in September to carry out the work in South Georgia, and on October 16 the R.R.S. William Scoresby left for the whaling grounds off Bouvet Island and Enderby Land on a whale-marking cruise. Mr. G. W. Rayner, who has conducted many of the earlier experiments, is scientific officer in charge, with Lieutenant C. R. U. Boothby in executive command.

\section{National Trust's New Property in Derbyshire}

By the generous gift of Mr. F. A. Holmes of Buxton, announced on October 10, Stanton Moor Edge, near Rowsley, Derbyshire, becomes the property of the National Trust. This body is already the owner of three properties in the immediate neighbourhood, Shining Cliff Woodlands at Ambergate, Duffield Castle and Taddington Wood. The new acquisition consists of 28 acres and is an escarpment, $900 \mathrm{ft}$. above sea-level, which forms a natural terrace a mile in length, looking out over moorland and the valleys of the Wye and Derwent. Not only is the view from this escarpment of great natural beauty, but it is situated in the middle of an area of exceptional interest for the historian and archæo- 